\title{
INVESTIGAÇÃO CLÍNICO-LABORATORIAL DE INFECÇÃO POR POLIOMAVÍRUS EM TRANSPLANTE RENAL
}

\author{
Polyomavirus infection in kidney transplantation \\ Juliana Montagner, Tatiana Michelon, Regina Schroeder, Alexandre Oliveira, Janaina Silveira, \\ Márcia Graudenz, Cláudio Alexandre, Jorge Neumann
}

\begin{abstract}
RESUMO
Centros que trabal ham com transplantes freqüentemente deparam-se com infecções oportunistas. I nfecções deste tipo são causa de morbimortal idade em pacientes imunodeprimidos e, por isso, dependem de ferramentas específicas para o seu diagnóstico. Considerando-se que a prevalência de infecções latentes pelos vírus da família dos poliomavírus, especial mente o BK V , é alta e que o sítio de latência de al guns vírus dessa família é o próprio tecido renal, os pacientes submetidos a um transplante de rim são especialmente vulneráveis aos danos de uma eventual reativação viral durante a imunossupressão profilática e terapêutica. 0 BKV tem sido associado ao desenvolvimento de estenose ureteral, levando à uropatia obstrutiva, ou à N efropatia associada ao BK V (BK N ), que resulta em disfunção progressiva e perda do enxerto, freqüentemente confundidas com processo de rejeição. Portanto, a suspeita clínica e a possibilidade de se real izar o diagnóstico definitivo e precoce de uma infecção por BKV é fundamental para se definir a sua terapêutica e prognóstico. 0 conhecimento da biologia viral, da fisiopatologia das doenças causadas por BKV e da eficácia diagnóstica dos diferentes testes laboratoriais disponíveis, permite a definição da melhor estratégia para o diagnóstico precoce das infecções por BKV e a monitorização das terapias específicas. 0 esquema proposto nesta revisão, para a investigação laboratorial em pacientes de risco e de monitorização da resposta ao tratamento em pacientes com doença comprovada por BKV , considera aspectos clínicos e laboratoriais, que facilitam o manejo destas infecções. Da mesma forma, os testes laboratoriais são hierarquizados considerando-se a sensibilidade, especificidade e complexidade técnica.
\end{abstract}

Descritores: Poliomavírus, Infecções por Poliomavírus, Transplante Renal, Diagnóstico

\section{Instituição:}

Fundação Faculdade Federal de Ciências Médicas de Porto Alegre Santa Casa de Porto Alegre - Laboratório de Imunologia de Transplantes Porto Alegre - RS

Correspondência:

Juliana M. Montagner

R. Coronel Corte Real, 311 / 702

CEP: 90630-080 - Porto Alegre - Rio Grande do Sul

Tel/Fax: 555132148670 / 32148629 / 99140526

E-mail: jmontagner@mixmail.com

Recebido em: 05/04/2006

Aceito em: 20/04/2006

\section{INTRODUÇÃO}

Com 0 advento dos transplantes, a necessidade de manejar pacientes imunodeprimidos trouxe consigo a obrigatoriedade da suspeita clínica de infecções oportunistas, quesão responsáveis por al ta morbimortalidade nesta população de pacientes. Bactérias efungos pouco patogênicos na população imunocompetente e, principalmente, vírus que fazem latência, passaram a ser, constantemente, agentes que colocam em risco os pacientes portadores de imunodeficiência primária ou adqui rida. N este contexto, centros que trabal ham com transplante de órgãos deparam-se com esta suspeita clínica muito freqüentemente e, portanto, necessitam de ferramentas para os respectivos diagnósticos específicos.

A família poliomavírus, a qual inclui dois vírus com potencial patogênico em humanos (JCV e BKV), tem alta prevalência de infecção na população em geral.1 Considerando que o sítio preferencial de latência do BK V é o próprio tecido renal, os pacientes submetidos a um transplante de rim são especialmente vulneráveis aos danos de uma potencial reativação viral durante a imunossupressão profilática e terapêutica dos processos de rejeição.

A reativação desta infecção pode comprometer a função e levar à perda do enxerto, à semel hança do que ocorre como conseqüência 
de uma rejeição. A nefropatia causada por BKV (BKN) é uma complicação que afeta o enxerto renal, precoce ou tardiamente após o transplante e que só recentemente tem sido uma preocupação entre os clínicos devido à sua dificuldade diagnóstica até o momento. Portanto, a suspeita clínica e a possibilidade de se realizar o diagnóstico definitivo e precoce de uma infecção por poliomavírus é fundamental para se definir a sua terapêutica e prognóstico.

O conhecimento da biologia viral, da fisiopatologia das doenças causadas por poliomavírus e da eficácia diagnóstica dos diferentes testes laboratoriais disponíveis, permitem a definição da melhor estratégia para o diagnóstico precoce das infecções por BKV e monitorização de terapias específicas. 0 presente estudo apresenta uma análise crítica da literatura internacional atual e propõe uma estratégia para o diagnóstico deste tipo de infecção em pacientes transplantados renais.

\section{DIAGNÓSTICO DE INFECÇÃO POR POLIOMAVÍRUS}

Existem diversos métodos diagnósticos para a identificação de uma infecção por BK V, seja ela latente ou ativa. Os diferentes testes podem ser aplicados em diversos materiais biológicos e cada um deles pode identificar estágios diferentes de uma mesma infecção nos diversos sítios. A lém disso, por possuírem acurácia distinta, sua informação, muitas vezes, dificulta a interpretação clínica.

Considerando-se que a população de risco é altamente suscetível a quadros clínicos irreversíveis e com alta morbidade, faz-se necessária uma estratégia diagnóstica, com sensibilidade suficiente para identificar precocemente os casos com potencial de evolução da infecção viral para doença e especificidade para minimizar o risco de perda do enxerto decorrente de uma redução inadvertida da imunossupressão para o controle da replicação viral. A escolha dos testes ainda deve contemplar a preocupação com o risco e 0 custo-benefício, com vistas à garantia da alta eficácia diagnóstica e viabilidade econômica em cada centro.

Embora o diagnóstico de BKN dependa da biópsia renal, existe um arsenal de técnicas disponíveis para auxiliar no diagnóstico. A tualmente, a microscopia óptica e eletrônica, a sorologia, a detecção de efeito citopático viral e métodos que identificam antígenos específicos ou o DNA viral, servem como ferramentas auxiliares para o diagnóstico e monitorização da BK N. Técnicas de imunohistoquímica têm sido aplicadas em espécimes de biópsia do enxerto renal. ${ }^{2,3} 0$ isolamento viral por técnicas moleculares tem sido aplicado em sangue, ${ }^{4}$ urina $a^{3,4}$ e biópsia, ${ }^{5}$ sendo uma ferramenta sensível e específica para o diagnóstico de infecções por BK V. Todos estes testes têm importância diagnóstica e podem ser empregados na monitorização da resposta terapêutica específica.

\subsection{SOROLOGIA}

0 estudo sorológico foi a primeira ferramenta utilizada para avaliar a prevalência do BK V na população humana. 0 teste primariamente mais empregado foi a inibição da hemaglutinação, que detecta os anticorpos IgG e IgM dirigidos contra antígenos do capsídeo viral. ${ }^{6} \mathrm{Hoje}$, numerosos testes de ensaio imunoenzimático (ELISA) estão disponíveis para medir as subclasses de imunoglobulinas produzidas, em resposta a antígenos virais específicos. ${ }^{7}$

Entretanto, a monitorização sorológica desta infecção é limitada, pois 70 a $88 \%$ dos receptores renais têm sorologia IgG positiva antes mesmo do transplante devido à exposição precoce ao vírus. ${ }^{8}$ A lém disso, a monitorização da IgM , apesar de identificar uma infecção viral ativa, pode não ser observada em pacientes imunossuprimidos, fazendo com que os testes sorológicos tenham um valor mais epidemiológico do que diagnóstico na rotina da investigação clínica em pacientes de risco. ${ }^{9}$

\subsection{ISOLAMENTO VIRAL EM CULTURA CELULAR}

0 isolamento do vírus em cultivo celular in vitro, não tem sido utilizado devido ao seu rendimento demasiadamente baixo, com perspectiva de isolamento viral variando de 0 a $1 \% .{ }^{9} \mathrm{~A}$ grande quantidade de resultados falso-negativos ocorre em função da neutralização viral por anticorpos presentes na urina e porque algumas formas variantes de regiões genômicas não codificantes do BKV não são passíveis de crescimento em cultivo celular empregando os substratos tradicionais. ${ }^{6}$

\subsection{CITOLOGIA URINÁRIA}

A morfologia de células epiteliais urinárias, avaliada através de coloração de Papanicolau, é um indicador da excreção de vírus na urina. Células epiteliais infectadas por vírus, chamadas de decoy cells, não são exclusivas de infecção por poliomavírus. ${ }^{10,11}$ A identificação de decoy cells não permite distinguir entre os membros da família poliomavírus - JCV, BK V, SV 40 (poliomavírus patogênico em macacos R hesus) - ou outras infecções virais. ${ }^{9}$ A lém disso, a excreção viral urinária pode ocorrer sem marcas citológicas anormais. ${ }^{10}$

A s decoy cells são células caracterizadas por apresentarem um aumento de volume nuclear, com núcleo basofílico, cromatina condensada e nucléolos evidentes (inclusão nuclear). Células infectadas por poliomavírus devem ser diferenciadas de células infectadas por CM V, que são geralmente menores, basofílicas ou eosinofílicas, rodeadas com um halo, e contêm inclusões intracitoplasmáticas. ${ }^{12}$

0 achado de decoy cells na urina pode indicar ativação de poliomavírus no trato urogenital e a ativação do BKV é um prérequisito para a doença viral parenquimatosa. Todos os casos de BK N apresentam decoy cells na urina no momento do diagnóstico inicial e, após a BK N ter sido resolvida, as decoy cells desaparecem do sedimento urinário. ${ }^{13}$

E ntre os pacientes com disfunção aguda do enxerto, a prevalência do achado de decoy cells é de $16 \%$. Biópsias renais destes pacientes com virúria confirmam BKN em $37 \%$ dos casos. ${ }^{14}$ A pesar do baixo valor preditivo positivo da citologia urinária $(<20 \%)$, seu valor preditivo negativo é de 80 a 100\%, 11,13,15 Por se tratar de uma técnica de fácil realização e de baixo custo, é uma ferramenta útil para a investigação da infecção ativa pelo poliomavírus e seleção dos pacientes que devem ser submetidos à biópsia do enxerto para a confirmação da BKN. A citologia negativa permite afastar a hipótese de BKN e outros diagnósticos devem ser considerados para justificar a disfunção aguda do enxerto. ${ }^{16}$ A figura 1 é um exemplo de decoy cell detectada no sedimento urinário através de coloração de Papanicolau.

\subsection{ANÁTOMO-PATOLÓGICO E IMUNOHISTOQUÍMICA}

A pesar de depender de procedimento invasivo, a histologia constitui o padrão ouro para o diagnóstico de BK N . ${ }^{6,17}$ A detecção 


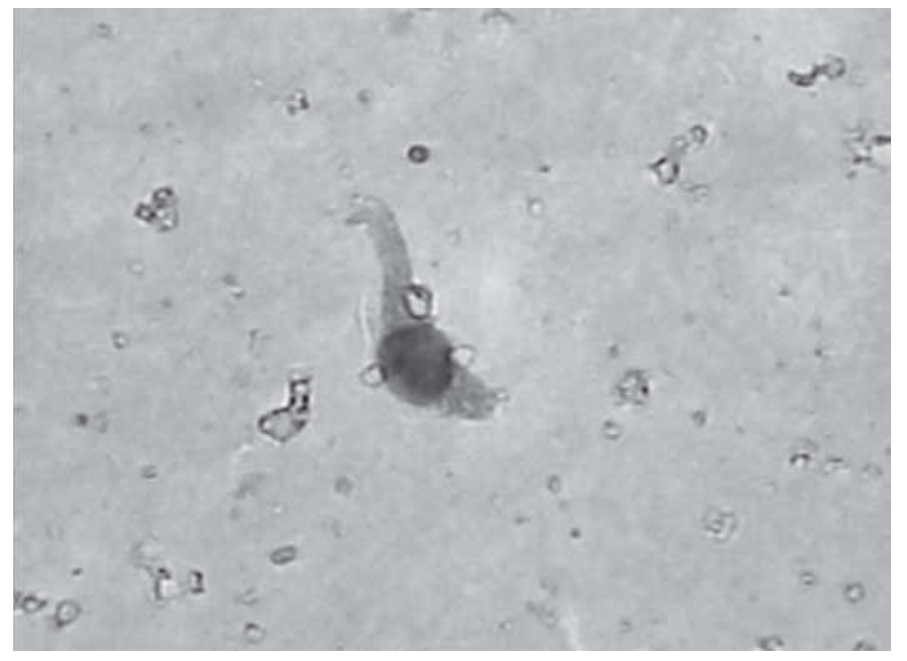

Figura 1: Decoy cell detectada no sedimento urinário de paciente com disfunção renal através de coloração de Papanicolau

Aumento $1000 x$

de inclusões virais nas células epiteliais tubulares indica a presença de infecção viral ativa no parênquima renal. ${ }^{18}$

Histologicamente, a replicação viral resulta no aumento do tamanho da célula às custas de aumento do volume nuclear onde 0 vírus está se multiplicando, fenômeno detectado à microscopia óptica como inclusões nucleares. A lém disso, os efeitos citopáticos virais são observados como lise das células epiteliais tubulares, o que resulta em desnudamento da membrana basal e induz uma resposta inflamatória intersticial.

Por vezes, o diagnóstico baseado somente na evidência anátomopatológica pode ser difícil, uma vez que ambos os achados característicos (células tubulares com inclusões virais e infiltrado inflamatório intersticial) podem ser falsamente interpretados como rejeição aguda. ${ }^{4} \mathrm{O}$ infiltrado intersticial linfomonocitário é um achado característico dos processos de rejeição aguda celular. A s célul as tubulares com inclusões nucleares, por sua vez, apesar de serem altamente sugestivas de infecção viral, podem ser confundidas morfologicamente com células gigantes típicas do processo de rejeição aguda ou representar infecção por outros vírus que não $0 \mathrm{BKV} \cdot{ }^{16,19}$

De qualquer forma, a definição e caracterização destes achados histológicos são de extrema importância, e sua classificação apresenta boa correlação prognóstica: padrão A (efeito citopático viral com nenhuma ou mínima inflamação); padrão B (lesão citopática ou citolítica com inflamação intersticial); padrão C (predominantemente fibrose intersticial e atrofia tubular, com variável efeito citopático e inflamatório). ${ }^{19}$

Considerando a inespecificidade destes achados, a detecção do antígeno ou do DNA do BKV no parênquima renal é necessária para a definição do diagnóstico de BK N. 20,21 Proteínas ou antígenos virais podem ser detectados por técnica de imunohistoquímica, DNA ou R NA viral por biologia molecular e/ou os vírions (40nm de diâmetro) podem ser identificados utilizando-se microscopia eletrônica.

A imunohistoquímica é real izada em amostras de tecidos fixados em formalina e parafinados. Utilizam-se anticorpos dirigidos contra antígenos de transcrição precoce (pré-replicação viral) próprios do
SV $40,{ }^{22}$ o qual reage contra antígenos comuns para SV 40, BKV e $\mathrm{JCV} .{ }^{3}$ A Iternativamente, anticorpos dirigidos contra a proteína do capsídeo viral podem também ser utilizados. ${ }^{23}$

A pesquisa do antígeno viral através da imunohistoquímica não é sensível o suficiente para detectar infecção viral latente. ${ }^{24}$ Todavia, o uso rotineiro da imunohistoquímica em todas as biópsias de enxerto renal geralmente não detecta nenhum caso de BK N além daqueles considerados suspeitos pelas características histológicas. Portanto, quando positiva, a imunohistoquímica permite confirmar que os achados da biópsia correspondem à infecção ativa por BKV no parênquima renal de pacientes com disfunção do enxerto e presença de decoy cells na urina. ${ }^{12} \mathrm{~A}$ figura 2 é um exemplo de BK N confirmada por imunohistoquímica.

Vale ressaltar ainda que, anatomicamente, o envolvimento do parênqui ma renal émultifocal epode ser encontrado tanto no córtex como na medula, embora os segmentos distais dos néf rons sejam mais freqüentemente afetados do que os segmentos proximais. ${ }^{19}$ Desta forma, diante da suspeita clínica, o estudo histológico, incluindo anátomo-patológico mais imunohistoquímica, deve sempre ser considerado juntamente com os resultados de virúria e viremia, pois o fragmento pode não ser representativo das áreas mais afetadas pela infecção viral. ${ }^{25}$

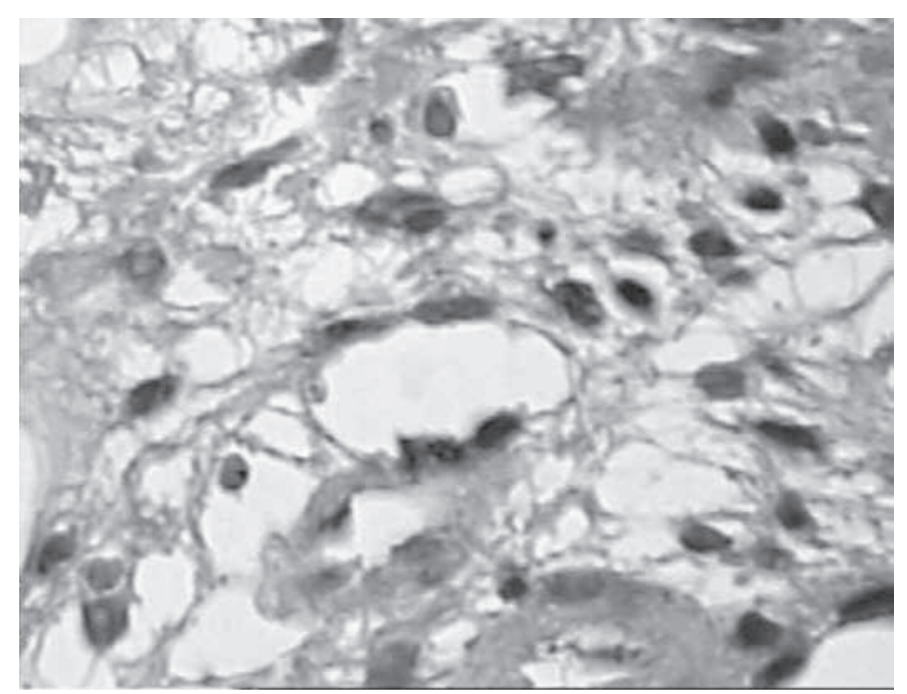

Figura 2: Detecção do antígeno do Poliomavírus em célula tubular renal e no interstício, indicando invasão intersticial

Imunohistoquímica positiva para poliomavírus em biópsia de enxerto renal. Aumento de 400x.

\subsection{TESTES MOLECULARES}

A identificação e quantificação do DNA ou RNA mensageiro (mRNA) têm sido úteis para o diagnóstico de muitas infecções virais como CM V, HIV e vírus E pstein B arr (EBV) e são cada vez mais aplicados para o diagnóstico e monitorização do tratamento de infecções virais, incluindo poliomavírus, ${ }^{3,26,27}$ O DNA ou mRNA viral pode ser detectado na urina, no sangue e em tecidos suspeitos, como biópsia de rim, que costuma ser o sítio de latência e de reativação da infecção por poliomavírus. ${ }^{26}$

Por serem técnicas com alta sensibilidade diagnóstica, a implicação clínica inclui o diagnóstico precoce, a avaliação da resposta a terapias antivirais e a monitorização de recidivas. A maior limitação 
dos testes baseados em DNA, especialmente os qualitativos, é que eles não podem distinguir entre infecção latente e reativação, ${ }^{27}$ sendo necessários testes quantitativos ou outros testes capazes de detectar antígenos ou seqüências de DNA expressos somente durante a replicação viral.

\subsubsection{TÉCNICAS DE PCR PARA DIAGNÓSTICO DE INFECÇÃO POR POLIOMAVÍRUS}

A escolha da melhor técnica deve sempre contemplar a maior sensibilidade e especificidade diagnóstica, a possibilidade de diferenciar a infecção latente da infecção ativa e a rapidez de obtenção do seu resultado, além da viabilidade econômica. Entre os diversos estudos publicados, as técnicas de PCR que vêm sendo aplicadas para o diagnóstico de infecções por BKV incluem 0 nested ${ }^{23}$ ou semi-nested-PCR ${ }^{28}$ e a PCR em tempo real. ${ }^{24,29}$

Seqüências de oligonucleotídeos complementares às da região precoce (transcrita antes da replicação do genoma viral),, ${ }^{23}$ tardia (transcrita após a replicação) ${ }^{5}$ ou da região controle de transcrição (região não codificante, chamada NCRR), ${ }^{30}$ podem ser usadas para amplificar parte do genoma do poliomavírus. A figura 3 representa de forma esquemática a estrutura genômica da família poliomavírus.

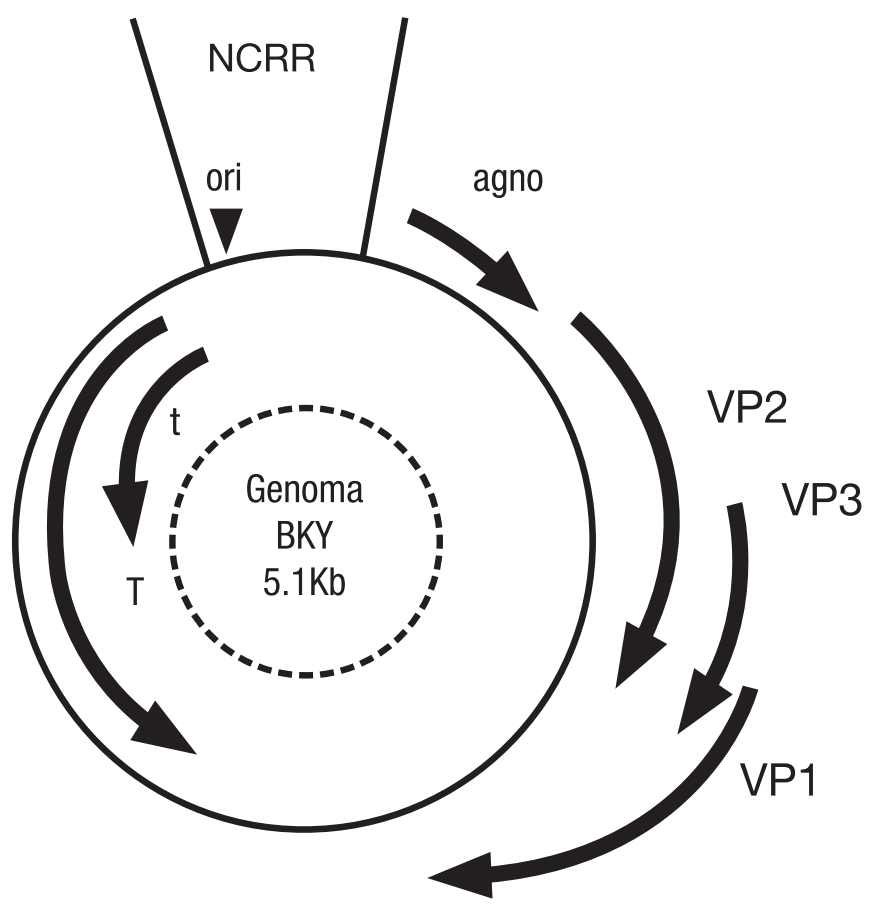

Figura 3: Estrutura Genômica da Familia Poliomavírus

Existe a possibilidade de diagnosticar apenas infecções em atividade quando se selecionam $\mathrm{mRNA}$ de antígenos tardios do $B K V$, tais como mRNA de VP1 e VP2, somente detectados em células infectadas com replicação viral. ${ }^{27}$

Utilizando-se um PCR quantitativo ainda é possível estimar a carga viral de cada paciente. A grande vantagem da quantificação da carga viral é identificar pacientes com um maior risco de BK N e monitorar a resposta à terapia através do aumento ou decréscimo da carga viral do BK V. ${ }^{31}$

\subsubsection{PCR EM DIFERENTES MATERIAIS BIOLÓGICOS} 2.5.2.1 PCR NA URINA

U tiliza-se com sucesso a detecção ${ }^{44,48}$ e quantificação do DNA 43,49 do poliomavírus, a partir de amostras de urina. ${ }^{24,27,32}$

Considerando-se que a BK N é caracterizada por replicação viral nas células tubulares, dano das células epiteliais, lise celular e necrose tubular aguda, 0 achado mais precoce é a identificação do DNA viral no sedimento de amostras de urina. ${ }^{4} \mathrm{~A}$ pesquisa de DNA viral na urina é uma ferramenta utilizada para determinar quais pacientes devem ter uma regular avaliação com pesquisa de D NA no plasma e submetidos à biópsia. Também é útil como monitorização da resposta ao tratamento antiviral, uma vez que, na urina, a PCR costuma negativar somente após a resolução da viremia. ${ }^{4}$

\subsubsection{PCR EM SANGUE, SORO OU PLASMA}

A origem do DNA do BKV no sangue não é clara, mas provavel mente, representa vírions ou DNA viral que replicam nas células epiteliais tubulares, trafegam via membrana basal lesada para capilares peritubulares, com restabelecimento da infecção sistêmica. A lternativamente, também é possível que o DNA do BK V no soro derive da replicação do BK V em tecidos extra renais. ${ }^{3}$ Portanto, a detecção do DNA viral na urina indica a presença de infecção do trato urogenital por poliomavírus e a sua identificação no sangue, soro ou plasma indica, de outra forma, a infecção ativa, ou seja, a existência de replicação viral. ${ }^{21}$

Dados preliminares sugerem que pacientes com viremia possuem altos níveis de DNA de BKV na urina comparados com pacientes sem evidência de viremia. ${ }^{30}$ Isto é reforçado pela observação de que nenhum paciente apresenta PCR positiva no sangue sem ter previamente $P C R$ positiva na urina. 0 inverso ocorre na modulação imune e resolução da doença, observando-se a negativação da PCR no sangue antes de haver a negativação urinária. ${ }^{33}$

Da mesma forma, pacientes inicialmente livres de infecções por poliomavírus, após o transplante, passam ater o DNA do BK V detectado por PCR no plasma durante o desenvolvimento da $\mathrm{BK} N$ e retornam à sua condição negativa inicial após a resolução da mesma. ${ }^{24}$

A viremia tem um valor preditivo de $62 \%$ para o desenvolvimento de doença, sugerindo que pacientes virêmicos têm alto risco para a progressão de nef rite intersticial rel acionada ao BKV e, portanto, têm indicação de biopsia renal para definir a causa da disfunção do enxerto. ${ }^{28}$ Isto foi adequadamente demonstrado através de técnica quantitativa utilizando PCR em tempo real, de modo que o DNA do BKV pode ser precocemente detectado no sangue de pacientes, antes mesmo do estabelecimento de lesão histopatológica e disfunção do enxerto em pacientes que desenvolveram BK N. ${ }^{7}$

Com isso, a utilização do sangue como material biológico para a pesquisa de DNA de BK V por PCR é um sensível e específico teste de screening, embora os resultados devam ser interpretados em conjunto com a clínica do paciente, estudos do sedimento urinário (decoy cells, PCR) e biópsia renal.,28

\subsubsection{PCR NA BIÓPSIA RENAL}

A detecção do DNA viral na biópsia é altamente sensível, com um valor preditivo negativo para BKN de $80 \%$ e valor preditivo positivo de $73 \%$. $^{34}$

É interessante observar que, apesar da sua alta sensibilidade, 
dificilmente detecta infecção latente. U m estudo multicêntrico europeu demonstrou que todos os receptores com disfunção do enxerto renal com DNA do BKV na biópsia (2,6\%) expressavam também RNA mensageiro do vírus, indicando sua replicação ativa. ${ }^{35}$ Isto sugere que a detecção de DNA do BKV (técnica convencional de PCR) pode ser empregada no tecido renal para diagnóstico de $B K N$, precoce 0 suficiente para identificar casos de infecção ativa mesmo na ausência de alterações histológicas e manifestação clínica da doença. ${ }^{34}$

Damesmaforma, testes quantitativos na biópsia, como o PCR em tempo real, podem auxiliar na identificação de pacientes com maior risco, permitindo o diagnóstico de BK N antes de haver comprometimento estrutural. U m estudo recente empregando esta técnica sugere que a presença de mais de 57 cópias por célula é capaz de estabelecer 0 diagnóstico de BK N com alta sensibilidade e especificidade. ${ }^{5}$

\subsection{ESTRATÉGIAS PARA DIAGNÓSTICOS E MONITORIZAÇÃO DA INFECÇÃO POR POLIOMAVÍRUS}

A seleção dos pacientes a serem investigados deve basear-se na avaliação inicial de suscetibilidade ao desenvolvimento de BKN e do risco de progressão para a perda do enxerto. Para alguns autores, ${ }^{13}$ pacientes de alto risco, como aqueles tratados para rejeição aguda e em uso de tacrolimus e micofenolato mofetil, devem ser monitorizados para o risco de desenvolvimento de BK N.

Os testes laboratoriais devem ser hierarquizados considerando-se a sensibilidade, especificidade e complexidade técnica necessárias individual mente, além de considerar a di nâmica viral em momentos de reativação. A triagem consta de uma aval iação do efeito citopático viral, através de coloração do sedi mento urinário para a pesquisa de decoy cells. U ma vez positiva, idealmente, deve-se realizar a pesquisa do DNA ou do mR NA do vírus na urina e, depois, no sangue.

Diante da presença de viremia, é mandatória a realização de biópsia do enxerto para análise do aspecto histológico, com pesquisa de BKV através de imunohistoquímica ou PCR específico no tecido renal, como mostra a figura 4. U ma vez estabelecido o diagnóstico e iniciado o tratamento, as mesmas técnicas devem ser utilizadas para a monitorização da resolução da doença, devendo ser observada, inicialmente, a negativação dos testes em sangue periférico, posteriormente na urina e final mente no parênquima renal.

Esta mesma dinâmica deveser obedecida quando da utilização de testes quantitativos durante monitorização de tratamento antiviral, os quais são soberanos para este fim. A carga viral na urina menor que 106 e carga viral no soro menor que 103 cópias/ml são consistentemente associadas à microscopia eletrônica negativa e ausência de decoy cells na urina. A mesma relação entre urina e soro se observa com estes testes, de modo que a carga viral é consistentemente mais alta, na ordem de $3 \log$, na urina do que no soro. ${ }^{3}$

\subsection{TRATAMENTO}

Cerca de $60 \%$ dos pacientes com BK N podem obter a sua resolução, maisfreqüentementeem pacientes com padrão histológico B nabiópsia inicial. A pesar do desaparecimento do vírus, a maioria dos pacientes desenvolve nef ropatia crônica do enxerto posteriormente. ${ }^{36}$

A tualmente, não há tratamento antiviral específico para doenças por poliomavírus. Uma alternativa para o controle da BK N é a redução da imunossupressão, com vistas ao controle da reativação

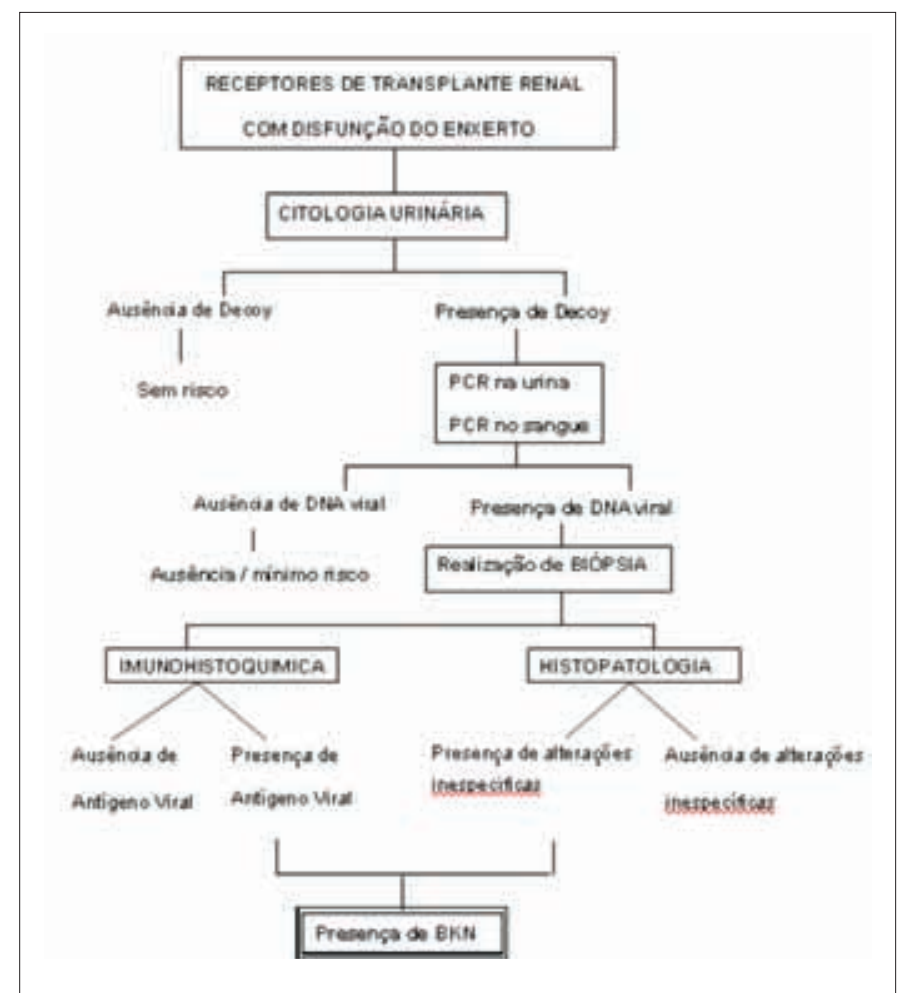

Figura 4: Algoritmo para diagnóstico de BKN

viral. 0 objetivo final é prevenção da progressão de viremia e doença. A implicação óbvia associada a esta estratégia éo aumento subseqüente do risco de rejeição. ${ }^{33}$

A coexistência da rejeição e da BKN é uma condição clínica complexa, uma vez que o tratamento de uma potencial mente agrava o curso clínico da outra. ${ }^{33} \mathrm{~A}$ imunossupressão intensa representada pelo tratamento dos episódios de rejeição aguda propicia o ambiente para a replicação viral.$^{37} \mathrm{~N}$ estas situações, a mel hor alternativa é 0 tratamento inicial da rejeição e, posteriormente, proceder-se à redução da imunossupressão. ${ }^{33}$

Estratégias de substituição de determinados imunossupressores mais fortemente associados ao desenvolvimento de doença por poliomavírus também têm sido utilizadas. 0 tacrolimus, um potente inibidor da calcineurina, utilizado como profilaxia e tratamento de episódios de rejeição aguda grave, figura no esquema imunossupressor de $70 \%$ dos casos de pacientes com BK N..$^{13}$ Por outro lado, foi sugerido recentemente que a introdução de sirolimus, um potente imunossupressor cujo mecanismo de ação é baseado na sua atividade anti-proliferativa, é capaz de prevenir a replicação viral nas células infectadas, restabelecendo a condição de latência viral. ${ }^{38}$

Como terapia antiviral específica, muitas drogas, incluindo derivados de ácido reti nóico, inibidores da DNA girase, arabinoside citosine e o cidofovir, têm se mostrado capazes de inibir a replicação do DNA do poliomavírus in vitro. ${ }^{39}$ Clinicamente, a redução da imunossupressão associada ao cidofovir e leflunomide, isolados ou combinados, tem sido efetiva na redução da carga viral no plasma na maioria dos pacientes, além de prolongar a sobrevida do enxerto e estabilizar a função renal em muitos casos de BK N. ${ }^{40,41}$ 


\subsection{CONCLUSÃO}

De uma forma geral, a presença de virúria isolada deve ser acompanhada clinicamente, porém nenhuma modificação do esquema imunossupressor ou terapia específica é recomendada. A partir do momento em que houver evidência de viremia persistente, deve-se reduzir a dose de inibidores de calcineurina, antes mesmo de se observar disfunção do enxerto. Caso não se atinja a negativação da viremia ou, ainda, ocorra disfunção do enxerto, recomenda-se a realização da biópsia antes de se proceder à diminuição da imunossupressão. Esta conduta é importante para que se estabeleça histologicamente o diagnóstico de BKN e se exclua a concomitância de rejeição.

H avendo a confirmação da BK N , deve-se reduzir a níveis mínimos os inibidores da calcineurina, devido à alta probabilidade de disfunção renal progressiva e perda do enxerto associadas à doença por BK V. ${ }^{21}$ A critério de cada centro, ainda pode-se lançar mão das terapias específicas ou substituição das drogas imunossupressoras para controle deste patógeno.

\section{ABSTRACT}

Transplantation centers often deal with opportunistic infections in immunocompromised patients. B esides the morbi mortal ity associated to them, specific technologies are necessary to define their diagnosis. Polyomavirus family has a high prevalence in a latent form in the renal parenchyma among the general population, representing a special risk for virus reactivation during the immunossupression in kidney transplant recipients. BKV infection is associated to ureteral stenosis, causing obstructive uropathy or a specific renal dysfunction, known as BKV N ephropathy (BKN). This last entity is characterized as a progressive decrease of the renal function up to reaching the graft loss, frequently misdiagnosed as a rejection. Clinical suspection and the potential for a specific viral diagnosis is crucial to set the therapeutic and the prognostic. The knowledge concerning the Polyomavirus biology, its physiopathological role and the efficacy of several available diagnostic tools help to define the better strategy to the early viral disease diagnosis and its monitorization under specific therapies. This paper describes a rationale for clinical investigation in high risk patients for BK N, discussing each laboratory test in a hierarchical way, based on their sensitivity, specificity and complexity.

Key words: Polyomavi rus, Polyomavirus Infections, K idney Transplantation, Diagnosis.

\section{REFERÊNCIAS}

1. Sha KV. Polyomaviruses. In: Fields BN, Knipe DM, Howley PM. Virology. Philadelphia: Lippincott-Raven. 1996;2027-43.

2. Rocha PN, Plumb TJ, Miller SE, Howell DN, Smith SR. Risk factors for BK polyomavirus nephritis in renal allograft recipients. Clin Transplant. 2004;18:456-62.

3. Tong CYW, Hilton R, Macmahon EME, Brown L, Pantelidis P, Chrystie IL, et al. Monitoring the progress of BK virus associated nephropathy in renal transplant recipients. Nephrol Dial Transplant. 2004;19:2598-605.

4. Vera-Sempere FJ, Rubio L, Moreno-Baylach MJ, Garcia A, Prieto M, Camañas A. et al. Polymerass Chain Reaction detection of BK vírus and monitoring of BK nephropathy in renal transplant recipients at the University Hospital La Fe. Transplant Proc. 2005;37:3770-3.

5. Randhawa PS, Rehman KK, Swalsky PA, Vats A, Scantlebury V, Shapiro R et al. DNA sequencing of viral capsid protein VP-1 region in patients with BK virus interstitial nephritis. Transplantation. 2002a;73:1090-4.

6. Randhawa P, Vats A, Shapiro R, Weck K, Scantlebury V. Polyomaviruses: BK virus: discovery, epidemiology, and Biology. Graft organ and cell transplantation. 2002c;5:19-27.

7. Hamilton RS, Gravell M, Maajor EO. Comparison of antibody titers determined by hemagglutination inhibition and enzyme immunoassay for JC virus and BK virus. J Clin Microbiol. 2000;38:105-9.

8. Gardner SD, Mackenzie E, Smith C. Prospective study of the human polyomaviruses Bk and JC and cytomegalovirus in renal transplant recipients. J Clin Pathol. 1984;37:578-86.

9. Kwak EJ, Vilchez RA, Randhawa P, Shapiro R, Butel JS, Kusne S. Pathogenesis and management od polyomavirus infection in transplant recipients. Clin Infect Dis. 2002;35:1081-7.

10. Ahsan N, Shah KV. Polyomaviruses: An overview. Graft organ and cell transplantation. 2002;5:9-18.
11. Gai M, Piccoli GB, Motta D, Giraudi R, Gabrielli D, Messina M et al. Detecting “decoy cells” by phase-contrast microscopy. Nephrol Dial Transplant. 2004;19:1015-23.

12. Drachemberg CB, Hirsch HH, Ramos E, Papadimitriou JC. Polyomavirus disease in renal transplantation review of pathological findings and diagnostic methods. Human Pathology. 2005;36:1245-55.

13. Nickeleit V, Steiger J, Mihatsch MJ. BK Virus Infection after Kidney Transplantation. Graft organ and cell transplantation. 2002;5:46-57.

14. Drachenberg CB, Beskow CO, Cangro CB. Human polioma virus in rebal allograft biopsies: morphologic findings and correlation with urine cytology. Hum Pathology. 1999;30:970-7.

15. Hirsch HH, Knowles W, Dickenmann M, Passweg J, Klimkait T, Mihatsch et al. Prospective study of Polyomavirus type BK replication and nephropathy in renaltransplant recipients. N Engl J Med. 2002;347:488-96.

16. Santos, RLS, Manfrinatto JA, Quadros KRS, Cia EMM, Carvalho RB, Alves G et al. Utilização da citologia urinaria como método de “screening” para infecção ativo pelo poliomavírus. J Bras Transpl. 2003;6:236-238.

17. Proceedings of the 7 th Clinicopathological conference on renal allograft pathology. Clin Transplant. 2004;suppl11;18:5-60

18. Randhawa PS, Demetris AJ. Nephropathy due to polyomavirus type BK. N Engl J Med. 2000;342:1309-15.

19. Liptak P, Kemeny E, Ivanyi B. Primer: histopathology of polyomavirus-associated nephropathy in renal allografts. Nat clin Pract Nephrol. 2006;2(11):631-6.

20. Fishaman JA. Bk virus nephropathy - Polyomavirus adding insult to injury. N Engl J Med. 2002;347:527-30.

21. Splendiane G, Cipriane S, Condo S, Paba P, Ciotti M, FavalliI C, Vega A, Dominijanni $\mathrm{S}$, Casciani CU. Polyoma virus an renal dysfunction in a transplanted population. Transplantat Proc. 2004;36:713-5. 
22. Namba Y, Moriyama T, Kyo M, Imamura R, Shi Y, Ichimaru N et al. Prevalence, characteristics, and outcome of BK virus nephropathy in Japanese renal transplant patients: analysis in protocol and episode biopsies. Clin Transplant. 2005;19:97-101.

23. Boldorine R, Veggiani C, Barco D, Monga G. Kidney and urinary tract Polyomavirus infection and distribution: molecular biology investigation of 10 consecutive autopsies. Arch Pathol Lab Med. 2004;129:69-73.

24. Vats A, Shapiro R, Randhawa PS, Scantlebury V, Tuzuner A, Saxena M. et al. Quantitative viral load monitoring and cidofovir therapy for the management of BK virus-associated nephropathy in children and adults. Transplantation. 2003;75:105-12.

25. Drachemberg CB, Papadimitriou JC, Hirsch HH, Wali R, Crowder C, Nogueira $\mathrm{J}$, et al. Histological patterns of polyomavirus nephropathy: correlation with graft outcome and viral load. Am J Transplant. 2004;4(12):2082-92.

26. Vats A. BK virus-associated transplant nephropathy: need for increased awareness in children. Pediatric Transplantat. 2004;8:421-5.

27. Ding R, Medeiros M, Dadhania D, Muthukumar T, Kracker D, Kong JM et al. Noninvasive diagnosis of BK virus nephritis by measurement of messenger RNA for BK virus VP1 in urine. Transplantation. 2002;74:987-94.

28. Nickeleit V, Klimkait T, Binet I, Isabelle F, Dalquen P, Del Zenero V et al. Testing for Polyomavirus type BK DNA in plasma to identify renal-allograft recipients with viral nephropathy. N Engl J Med. 2000;342:1309-15.

29. Poduval RD, Meehan SM, Woodle ES, Thistlethwaite JR, Haas M, Cronin DC et al. Successful retransplantation after renal allograft loss to polyoma virus interstitial nephritis. Transplantation. 2002;73:1166-9.

30. Ginevri F, Santis R, Comoli P, Pastorino N, Rossi C, Botti G et al. Polyomavirus BK infection in pediatric kidney-allograft recipients: a single-center analysis of incidence, risk factors, and novel therapeutic approaches. Transplantation. 2003;75:1266-77.

31. Limaye AP, Jerome KR, Kuhr CS, Ferrenber J, Huang M, Davis CL et al. Quantitation of BK virus load in serum for the diagnosis of BK virus-associated nephropathy in renal transplant recipients. J Infect Dis. 2001;183:1669-72.
32. Lee KW, Lee HH, Lee DS, Kim SJ, John JW, Oh HY et al. Polimerase chain reaction for the diagnosis of human Polyomavirus-associated nephropathy in renal transplant recipients. Transplant Proc. 2004;36:2116-7.

33. Agha IA, Brennan DC. BK Virus and Current Immunosuppressive therapy. Graft organ and cell transplantation. 2002;5:65-72.

34. Mannonn RB. Polyomavirus nephropathy: What have we learned? Transplantation. 2004;77:1313-8.

35. Schimid H, Nitschko H, Gerth J, Kliem V, Henger A, Cohen CD, et al. Polyomavirus DNA and RNA detection in renal allograft biopsies: results from a European multicenter study. Transplantation. 2005;80(5):600-4

36. Garber LW, Egidi MF, Stratta Rj, Lo A, Moore LW, Gaber Ao. Clinical utility of histological features of polyomavirus allograft nephropathy. Transplantation. 2006;82(2):196-204

37. Binet I, Nickeleit V, Hirsch H. Polyomavirus infections in transplant recipients. Transplantation. 2000;5:210-6.

38. Wali KR, Drachenberg C, Hirsch HH; Papaadimitriou J, Nahar A, Mohanlal V, et al. BK Vírus-associated nephropathy in renal allograft recipients:rescue therapy by sirolimus-based immunosuppression. Transplantation. 2004;78:1069-73.

39. Scantlebury V, Shapiro R, Randhawa P, Weck K, Vats A. Cidofovir: A method of treatment for BK Virus-associated Transplant Nephropathy. Graft organ and cell transplantation. 2002;5:82-7.

40. Hariharan S. Bk virus nephritis after renal transplantation. Kidney Int 2006;69(4):655-62

41. Kuypers D R J, Vandooren AK, Lerut E, Evenepoel P, Claes K, Snoeck R et al. Adjuvant Low-dose Cidofovir therapy for BK polyomavirus interstitial nephritis in renal transplant recipients. Am J Transplant. 2005;5:1997-2004. 